\title{
JAN NOVÁK, JIŘÍ TRNKA A JEJICH KYBERNETICKÁ BABIČKA
}

V loňském roce jsme si připomněli výročí sta let od narození výjimečného umělce, výtvarníka a průkopníka českého animovaného a loutkového filmu, Jiř́iho Trnky. K tomu přistupuje další výročí, a sice padesáti let vzniku filmu Kybernetická babička. Počínaje tímto filmem Jiří Trnka zahájil spolupráci s brněnským skladatelem Janem Novákem.

Jan Novák (Nová Říše, 8. 4. 1921 - Neu Ulm, 17. 11. 1984) byl typem skladatele, který byl postižen dvěma diktaturami. Během té první bylo jeho studium skladby, klavíru a dirigování na brněnské konzervatoři přerušeno nuceným nasazením v Německu, vůči té druhé se vymezoval jako svobodně jednající jedinec, což mu přinášelo četné nesnáze a nakonec vyústilo v emigraci v r. 1968.

Jako žák V. Petrželky, P. Bořkovce, A. Coplanda a B. Martinů se po návratu z USA v únoru 1948 etabloval jako jeden z nejtalentovanějších skladatelů své doby. Bezpečně ovládl jak komorní, tak symfonickou sazbu, což dosvědčoval orchestrálními cykly, symfoniemi, koncerty, balety, kantátami (monumentální Didó z r. 1967) a v šedesátých letech zejména hudbou k filmům K. Kachyni, V. Jasného, K. Zemana a J. Trnky.

Jeho kompoziční styl vycházel z neoklasicismu Stravinského a Prokofjevova typu, obohaceného o rysy jazzu. Po krátké epizodě tvorby v intencích Nové hudby počátkem šedesátých let se vrací k syntetickému stylu na bázi neoklasicismu s patrnými retrospektivními aluzemi na tvorbu Leoše Janáčka.

Léta v exilu prožil s rodinou v Dánsku, Itálii a Německu. Zejména italské působiště poblíž Lago di Garda zřejmě silně rezonovalo s jeho sklony k románské kultuře. Také proto byl skladatel donedávna pohřben v blízkém Roveretu, odkud byly jeho ostatky v r. 2011 slavnostně převezeny na brněnský Ústřední hřbitov.

Zcela zásadní roli pro vývoj Novákova stylu měl latinský jazyk. Novák jej studoval, překládal do něj, psal vlastní poezii (např. v reakci na r. 1968 vznikla sbírka Incursus barbarorum) a na základě jeho metra také komponoval. Své poznatky pak shrnul v teoretické publikaci Musica Poetica Latina vydané posmrtně. 
MARTIN FLAŠAR

\section{Kybernetická babička jako reflexe teorie kybernetiky}

Film Jiř́ho Trnky Kybernetická babička z roku 1962 je reprezentativním produktem své doby. Představuje silně kritickou reflexi dobových trendů ve vývoji vědy a techniky.

Linie př́běhu loutkového sci-fi horroru - jak zní vyčerpávající žánrové vymezení filmu - je poměrně prostá. V blíže neurčené budoucnosti vnučka opouští svou babičku, která se o ni stará, aby navštívila rodiče, kteří pracují kdesi hluboko v kosmu. Když její meziplanetární let dorazí na místo určení, uvítá ji alternativní - kybernetická babička. Její snaha rozptýlit holčičku hrami zvolna přechází od lehčích forem manipulace po šikanu a pronásledování. V okamžiku nejhlubšího zoufalství se objevuje fyzická babička, která vnučku přichází zachránit. Otázka, kterou si musíme v této souvislosti položit, je, odkud vlastně pramení tato kritická vize technologické budoucnosti?

Počátkem 60. let dochází v českém prostředí k poměrně intenzivní reflexi teorie kybernetiky. V roce 1960 vychází v českém překladu Wienerova Kybernetika ${ }^{1}$ a o tři roky později Kybernetika a společnost ${ }^{2}$ téhož autora. V roce 1961 zavítal do Československa průkopník americké počítačové hudby Lejaren A. Hiller a jeho př́spěvek nazvaný Elektronická hudba se později objevil v encyklopedii Věk kybernetiky. ${ }^{3}$ V roce 1964 vydal Vladimír Lébl překladový sborník studií Nové cesty hudby ${ }^{4}$ věnovaný Nové hudbě, EA hudbě a možnostem aplikace principů kybernetiky v hudební analýze. V něm se objevily např. studie Abrahama Molese Uvedení do současného stavu hudby a Joela Cohena Teorie informací $a$ hudba. Důležitým př́spěvkem k domestifikaci aplikované teorie byla studie domácího autora Antonína Sychry Hudba a kybernetika, publikovaná také v tomto sborníku. Sychra se v ní zabývá možností využití samočinných počítačů k analýze strukturálních zákonitostí lidových písní.

V roce 1963 byla v rámci Svazu československých skladatelů založena Kybernetická komise v čele s muzikologem Vladimírem Léblem. Tato komise zorganizovala $\mathrm{v}$ následujícím roce první seminář elektronické hudby v Československém rozhlasu v Plzni. V roli odborníků se zde představili skladatel Miloslav Kabeláč (1908-1979) a Eduard Herzog. Veškeré toto dění logicky stimulovalo a směrovalo kreativitu umělců a zároveň sytilo soudobou hudbu a umění bezmála futuristickými vizemi.

V kontextu české filmové tvorby dochází počátkem 60 . let $\mathrm{k}$ růstu produkce $\mathrm{v}$ oblasti vědecko-fantastického filmu. Mezi průkopníky tohoto žánru u nás patřil

1 WIENER, Norbert. Kybernetika: neboli řizeni a sdělování v živých organismech a strojích. Praha: Státní nakladatelství technické literatury, 1960.

2 WIENER, Norbert. Kybernetika a společnost. Praha: Československá akademie věd, 1963.

3 Věk kybernetiky: populární encyklopedie. Praha: SNTL - Nakladatelství technické literatury, 1966.

4 LÉBL, Vladimír - MOKRÝ, Ladislav. Nové cesty hudby: sborník studii o novodobých skladebných směrech a védeckých názorech na hudbu. Praha: Státní hudební vydavatelství, 1964. 
Karel Zeman (Cesta do pravěku, 1955; Baron Prášil, 1962), Jindřich Polák (Ikarie XB1, 1963) či Jiří Trnka a jeho film Kybernetická babička (1962). Skladateli hudby k těmto vědecko-fantastickým filmům byli Emil František Burian, Zdeněk Liška (1922-1983) a také brněnský skladatel Jan Novák. Pro tento typ tvorby měl vynikající výchozí pozici, která byla dána především jeho exkluzivním postavením v rámci brněnské kompoziční školy, flexibilitou, pílí a talentem. Dále téměř totálním zákazem skladatelské činnosti, kterou si vysloužil svým odmítavým postojem k vládnoucí moci. Je paradoxní, že tento zákaz z neznámého důvodu nezahrnoval filmovou hudbu.

Výsledkem této nedůsledné represe jsou filmové hudby ke čtrnácti celovečerním, jednomu animovanému a dvěma loutkovým filmům předních režisérů 60 . let - Karla Kachyni, Karla Zemana, Jiř́ího Brdečky, Jiřího Seqense, Vojtěcha Jasného a dalších.

K filmu se Jan Novák propracoval už v padesátých letech komponováním hudby pro Krátký film, který měl sídlo v Praze s pobočkami v Brně a Zlíně. V pozůstalosti skladatele uložené $\mathrm{v}$ rodinném archivu se nacházejí partitury $\mathrm{k}$ dokumentům z nejrůznějších oblastí: sportu, strojírenství, botaniky, antropologie, enologie apod. Je tedy evidentní, že vzhledem ke kvantitě i kvalitě produkce filmové hudby se Jan Novák řadí k nejvýznamnějším českým skladatelům filmové hudby a v kontextu Brna se jedná o bezprecedentní př́ipad. Jiř́ Trnka Nováka využil jako náhradu za svého „dvorního“ skladatele Václava Trojana. Z jejich spolupráce vzešly dva loutkové filmy: Kybernetická babička (krátkometrážní loutkový sci-fi horror), Archanděl Gabriel a Paní husa (krátkometrážní loutkový film podle Bocacciova Dekameronu).

V tomto období měl Trnka před sebou poslední dekádu svého života (zemřel v roce 1969), kdy vytvářel myšlenkově závažné a kritické filmy. Ve velké většině Trnkových filmů jsou postavy převážně němé, mluvené slovo zde hraje jen marginální roli. $\mathrm{O}$ to důležitější roli zde hraje hudba a ruchy. $\mathrm{Z}$ předešlých filmů víme, že Trnka si Trojanovy vážil natolik, že jí byl ochoten vizuální složku přizpůsobovat. Někdy dokonce přepracovával již hotové filmové scény. ${ }^{5}$ Lze se domnívat, že tento model spolupráce volil i v př́ípadě Jana Nováka.

\section{Kybernetická babička}

Pro skladatele filmové zrejmě neexistuje větší výzva než komponovat hudbu ke sci-fi filmu. Vazby na realitu tu bývají nejslabší, a tak autor hudby není limitován mimetickými nároky vizuální složky. Naopak bývá motivován ke konstrukci alternativní reality prostřednictvím hudby.

Skica filmové partitury z pozůstalosti Jana Nováka pracuje s obsazením smyčcového orchestru. Obsahuje hudbu k osmi scénám filmu: Hra s míčem, Hudba

5 České noviny.cz [online]. c2011 [cit. 2010-02-10]. Jiří Trnka. Dostupné z: <http://www. ceskenoviny.cz/zpravy/jiri-trnka-vdechl-svym-loutkam-zivot/412246>. 
sfér, Scherzo col legno, Kapky, Valčík, Dětská hra I a II, Ukolébavka. Tuto hudbu Novák ovšem evidentně nepoužil.

Hudební materiál filmu, který má 27,5 minuty využívá několik typů materiálu:

1. Originální hudbu čistě akustických, případně elektronicky manipulovaných nástrojů. Jako ukázku můžeme použít konkrétní situaci, kdy počítač generuje číslo letu (čas filmu: 7:45 - 8:29). Novák zde obsadil klavír, vibrafon a bicí nástroje. Stylově paroduje serialismus na úrovni mezi postwebernismem a Stravinským.

2. Přejatou hudbu cizích autorů. Při letu kosmickou lodí zní montáž Mozartovy, Čajkovského a Chačaturjanovy hudby (čas filmu: 10:00 - 11:37).

3. Mluvené slovo, které je melodicky zdvojováno hudební linkou. Tento princip nacházíme u Leoše Janáčka nebo daleko později u Steva Reicha, který se na Janáčka odvolává. Objevuje se např. v projevu kybernetické babičky (čas filmu: $18: 34-19: 22)$.

4. Techniku leitmotivu. Pro definování postavy reálné babičky a pocitu domova a bezpečí Novák použil varhany - jednak jako tradiční nástroj spojený s duchovním životem českého venkova, jednak jako znak vis maior (čas filmu: 26:47 - 27:27). Varhany zde fungují výhradně jako znak, konkrétní hudební obsah jejich partu má k výše zmíněným konotacím daleko.

Na závěr uved'me pozoruhodnou skutečnost, že práce s elektronicky manipulovanou hudbou ve filmu Jiř́ího Trnky se časově překrývá s Novákovými experimentálními kompozicemi s EA složkou v oblasti autonomní hudby. Jsou to kompozice jako Dulces cantilenae na Jana Campana Vodňanského (1963) či Ioci vernales se zpěvem ptáků na mgf. pásu (1964). Není tedy nepravděpodobné, že k elektroakustické hudbě (resp. elektronicky manipulované akustické hudbě) se Novák dostává prostřednictvím hudby $\mathrm{k}$ animovanému filmu, který pro tento typ manipulací skýtá ideální pole. V př́ípadě Kybernetické babičky dochází částečně k jakési ironické situaci: ke zpochybnění základních premis kybernetiky Novák používá prostředky kybernetické hudby a spolu s Jiřím trnkou útočí na její mytologii jejími vlastními prostředky.

Martin Flašar je odborným asistentem Ústavu hudební vědy FF MU. Své bádání zaměřuje na vztah hudby a techniky, multimédií, tvorbu Jana Nováka a jeho současníků.

\footnotetext{
ABSTRACT:

The puppet film Cybernetic Grandmother (1962) by Jiří Trnka with music by Jan Novák represents an example of a critical attitude towards basic premises of cybernetics widely consumed in Czechoslovakia in 1960s after publishing the translation of Norbert Wiener's seminal work. Novák in cooperation with Trnka provides here a certain deconstruction of cybernetic mythology by its own truest means.
} 


\section{Key words:}

Jan Novák, Jiří Trnka, Cybernetic Grandmother, animated film, cybernetics, electronic music

\section{Bibliography:}

České noviny.cz [online]. c2011 [cit. 2010-02-10]. Jiří Trnka. Dostupné z: <http://www.ceskenoviny.cz/zpravy/jiri-trnka-vdechl-svym-loutkam-zivot/412246>.

LÉBL, Vladimír - MOKRÝ, Ladislav. Nové cesty hudby: sborník studii o novodobých skladebných směrech a vědeckých názorech na hudbu. Praha: Státní hudební vydavatelství, 1964.

Věk kybernetiky: populárni encyklopedie. Praha: SNTL - Nakladatelství technické literatury, 1966. WIENER, Norbert. Kybernetika: neboli řizeni a sdělování v̌ivých organismech a strojich. Praha: Státní nakladatelství technické literatury, 1960.

WIENER, Norbert. Kybernetika a společnost. Praha: Československá akademie věd, 1963. 
